Original Article

\title{
Fact-checking initiatives as promoters of media and information literacy: The case of Poland ${ }^{*}$
}

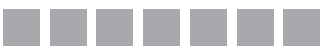 \\ Michał Kuś \\ ORCID: 0000-0001-8300-5162 \\ UNIVERSITY OF WROCLAW \\ Paulina Barczyszyn-Madziarz \\ ORCID: 0000-0003-1335-7386 \\ UNIVERSITY OF WROCLAW
}

https://doi.org/10.19195/1899-5101.13.2(26).6

\begin{abstract}
The main purpose of the article is to present the role and importance of Polish factchecking initiatives in context of their educational dimension. The central question that the authors will try to answer is: To what extent and in which way do the Polish fact-checking initiatives provide education as part of their activities? To answer this question, the authors implemented a two-step research design - starting from desk research concerning the development of Polish fact-checking scene and its social, political, economic and cultural background. The second step included in-depth, semi-structured interviews with five representatives of different types of Polish fact-checking initiatives. Considering a limited number of fact-checking organizations in Poland, the authors can assume a certain level of generalizability of the results of such qualitative research. The study shows that studied initiatives are occasionally active in the field of media and information literacy, and only some of them (i.e. mostly those related to civil society groups) treat their educational activities as a priority.
\end{abstract}

KEYWORDS: disinformation, fake news, fact-checking, fact-checking initiatives, media and information literacy (MIL), Poland

\section{INTRODUCTION}

As McQuail (2020, p. 4) suggested, despite changes there is no doubt about the continuing significance of mass media in modern society - in the areas of politics,

* This work received support from the European Union ERASMUS+ Strategic Partnership project "Media and Information Literacy \& Innovative Teaching Methods Laboratory" No. 2017-1-LV01KA203-035429. 
culture, everyday social life and economics. The importance of mass media in contemporary societies is obvious, same as political actors' activity aimed at appearing in the media (both traditional and new) and being quoted to influence public agenda.

Unfortunately, opportunities created recently by the development of digital media are also exploited in very iniquitous ways, and the weaponization of digital platforms has become reality. Waves of disinformation and the development of fake news production practices, especially in online media, are increasingly visible and relevant phenomena, influencing political, economic and social processes in many countries (Bradshaw \& Howard, 2018). An example could include the case of Russia's activity in the field of disinformation, which was described by Freedom House (2018): "Vladimir Putin's Russia has carried out disinformation campaigns before elections in countries including the United States, France, and Germany (...)". Moreover, some studies suggest that false news spread more rapidly on the social network than real news does (Dizikes, 2018; Vosoughi et al., 2018). In consequence, the present authors observe some very alarming tendencies in public communication, related to the growing influence of populist messages, hate speech, polarization of attitudes and radicalization of certain groups in societies. (Farkas \& Schou, 2019) In the case of Poland, some elements of disinformation, also contributing to polarization and radicalization of attitudes in society, was the topic of migration and asylum as well as LGBT community ("LGBT ideology") in the 2019 election campaigns. There was presence of narrative schemes regarding alleged threats associated with the presence of people with these two groups (Helsińska Fundacja Praw Człowieka, 2020). Hence, certain "vulnerabilities" in digital technologies have a direct or indirect impact on individuals and social groups, influencing the gradual erosion of trust in the public sphere, which often has devastating impact on the quality of public communication and public life in general (Flore et al., 2019; Bennett \& Livingston, 2018).

Ongoing discussions concerning disinformation, fake news, and post-truth intensified, especially from year 2016, with the US presidential elections and the Brexit referendum. Furthermore, their influence on contemporary societies (Bennet \& Livingston, 2018), as well as their role of evaluating information (Wineburg et al., 2016), recently considered the necessity of fact-checking and analyzed different potential forms of this type of activity.

However, apart from their main purpose, which is examining the veracity of information circulating the public sphere, fact-checking initiatives could also be considered as potentially effective Media and Information Literacy (MIL) tools. Both of them promote a critical approach to public debate and put emphasis on critical thinking skills. The report, Mapping of media literacy practices and actions in EU-28 (European Audiovisual Observatory, 2016), also confirms that the role of this MIL element is important in public initiatives. "Critical thinking" was pointed out in 403 of the 547 projects which were analyzed by experts.

In this article, the authors aim at analyzing fact-checking organizations' potential in this area, putting this analysis within the context of the case study of Poland. 
Apart from specific features of Polish media system, investigating Polish fact-checking scene requires some additional information about the recent phase of political and social development of the country.

First of all, in the 2010s, Poland faced relatively high levels of political and social polarization. Therefore, even if the present authors assume that such polarization is nowadays quite a common feature of European democracies, the situation in Poland seems to be even more complicated (Głowacki \& Kuś, 2019), and some country-specific developments concerning public communication are observed in the last decade. It includes: (a) creation of two-filter bubbles (conservative and liberal one), especially after 2010 Smolensk plane crash, in which President Lech Kaczyński and 95 other representatives of Polish elites died; (b) the wave of radical political statements and activities (e.g. anti-liberal, anti-LGBT, anti-EU but also vice versa); and (c) growing hostility of certain social groups towards each other.

It also means that there are specific challenges for fact-checking in today's Poland. Since Polish fact-checking organizations operate in such polarized political and social environments, they may be easily accused, for example, for liberal, leftist or conservative bias in their activities. Nevertheless, such restrictions do not stop Polish factchecking scenes from developing and, in some dimensions, even flourishing. Rapid growth between the years 2017 and 2019, in terms of the number of fact-checking initiatives, seem to confirm that Polish political and media ecology is facing the same development patterns as other European democracies. At the same time, the quality and dynamism of certain fact-checking organizations within Poland differ significantly.

All of the above-mentioned developments and challenges faced by Polish media, politics, and society also mean that there is an important role to be played by the Polish fact-checking organizations, both in terms of their core activities, as well as from the point of view of their potential educational dimension. The latter seems to be especially relevant in Poland, where media education is still institutionally underdeveloped. The Media Literacy Index 2019, ranking countries according to their MIL resources, showed that Poland had 53 points (on a 0-100 scale), holding the 18th position in the group of 35 European countries (Lessenski, 2019, p. 5).

\section{DEFINITIONS AND OPEN QUESTIONS}

Vocabulary related to different forms of information disorders has been recently developed significantly, and especially after 2016 a set of concepts and words related to this area became relevant, for experts, media, and the public.

The concept of fake news probably focused public attention in the most visible way. Fake news could be understood broadly as for-profit fabrication, politically motivated fabrication, or malicious hoaxes (Nielsen \& Graves, 2017). However, among academics and experts, the other concepts are in use, rather than fake news. For example, Wardle and Derakhshan (2017, p. 21) pointed out in the Council of Europe Report, there are three types of information disorder: (1) dis-information, which is false and created to 
harm a person, group, or organization; (2) mis-information, which is false but not created with the aim to cause harm; and (3) mal-information, which is based on reality but is used to harm a person, organization, or country. In this text, the authors use term disinformation, referring to the most harmful form of information disorders.

Often, disinformation is associated with the efforts of the radical political actors to mobilize and organize supporters against parties in the center and mainstream media (Bennett \& Livingstone, 2018). In this context, MIL could be considered a crucial competency in today's societies and one of the most effective tools for counteracting fake news, as well as promoting independent, pluralistic media and information systems. Fact-checking, as such, becomes one of the most important processes, aimed at safeguarding the high quality of democratic public spheres.

\section{Fact-checking as a response to disinformation}

The concept of fact-checking is not new. The first organizations that aimed to publicly evaluate if the political statements are true appeared in the United States (US) in the early 2000s, including Spinsanity (2001) and FactCheck.org (2003). In Europe, the first fact-checking initiative was launched by British Channel 4, on the occasion of the United Kingdom (UK) parliamentary elections in 2005 (Graves \& Cherubini, 2016, p. 6).

Fact-checking is rooted in journalism and relates to procedures of verifying facts before publication, but it could also be understood as publicly evaluating the truth of statements made by politicians, journalists, and other public figures (Graves \& Amazeen, 2019; Graves, 2016). However, the beginning of second decade of the twenty-first century can be seen as a completely new phase of development for factchecking, with the growth of digital media as the principal context factor in this respect. From this perspective, fact-checking may be seen as a reaction to massive growth of information available in the public sphere, but most of all towards the uncontrolled spread of disinformation. This recent idea of fact-checking, as being principally a digital practice, appeared at the end of the twentieth century, but research shows that the largest development of fact-checking internationally took place between the years of 2015 and 2017 (Flamini, Tardáguila, \& Örsek, 2019).

Events like the US presidential elections and Brexit referendum are frequently seen as turning points, initiating dynamic waves of fact-checking - firstly, in the Anglo-Saxon world and, then, globally. In Poland, such turning points were the presidential and parliamentary elections in 2015, won by the Law and Justice party and its presidential candidate Andrzej Duda. In turn, its implications are perceived mostly in terms of the growing level of political and social polarization and conflict.

\section{Types of fact-checking initiatives}

Fact-checking initiatives usually function as part of editorial offices or as independent non-governmental organizations, less often in the academic community. Graves 
and Cherubini (2016, p. 8) divided fact-checking organizations in terms of their methods and mission in the following groups: reporters, reformers, and experts. The first group is focused on providing information for citizens and includes mostly fact-checking operations of established media outlets (i.e., French Le Monde or British Guardian). The second group is mainly focused on promoting changes and development in politics and media, including mostly groups of activists and NGOs (e.g., FactCheck Ukraine or Romanian organization Funky Citizens). The third group mainly focuses on preserving their role as independent experts, usually with academic backgrounds, and probably the best example is the Conversation, Australian initiative that was established in 2011 and later expanded to many other countries (Graves \& Cherubini, 2016, p. 12-18).

Fact-checking organizations can also be classified according to who's operating them, with media organizations, NGOs, and academic institutions (Flamini et al., 2019) being the most important actors in this respect. This classification will be later used to distinguish different types of fact-checking initiatives in Poland (see section dedicated to their description).

\section{The educational potential of fact-checking initiatives}

As mentioned before, fact-checking initiatives could essentially be seen as important tools for MIL, which empower people with access to information and knowledge, as well as promote critical thinking skills. They help to deal with the problem of distinguishing the truth from falsehood and manipulation in the public space. Additionally, fact-checking initiatives can reveal the mechanisms behind disinformation and manipulation by de-constructing the process of false news creation. There are studies in the literature, which also show MIL as a tool to counter hate and radicalization (Grizzle, 2016). As Carlsson (2019) writes, "MIL is a part of media development and the democratization process - which involves all people around the world" (p. 19).

Fact-checking is practical in itself. Sometimes fact-checkers are described as the umpires of democracy, whose goal is to keep false claims out of the public debate (Lim, 2018). Fact-checking websites aim to correct disinformation and make politicians accountable by providing coverage of the accuracy of statements made by political actors (Agadjanian et al., 2019). It provides knowledge and promotes critical thinking in public discourse.

Fact-checking can be regarded as important in countries like Poland, where there have been some objections to the approach to media education, and in which MIL is typically understood in a narrow way and connected mainly with IT skills (see Grzegorz Ptaszek's interview in this issue). Comparisons have shown that Europe exhibits a great variation in their approaches to MIL; whereas, Western countries more often understand MIL as rooted in media education, and Eastern countries more easily associate it with computer skills and information skills (Frau-Meigs et al., 2017, p. 32). 
Fact-checkers often teach how to search for reliable sources of information and how to distinguish facts from fake news (see, e.g., Jaakkola, 2018). Those kinds of organizations and groups often set themselves the task of educating society and raising awareness of disinformation on the Internet. They often offer training, workshops, and lectures. An example from Poland is the "Fact-Checking Academy" created by Demagog, which will be described later in the section dedicated to Polish fact-checking organizations.

\section{RESEARCH QUESTIONS}

The aim is to gain an overview of fact-checking organizations in the Polish context at a certain point of time, specifically at the beginning of the year 2020. Considering the above-mentioned context, the authors aimed at responding to a set of questions. The overarching question that the authors will try to answer is as follows:

RQ0: To what extent and in which way do the Polish fact-checking initiatives provide education as part of their activities?

This question is broken down to three more detailed research questions that read as follows:

RQ1: How and to what extent is the educational function declared as part of the mission of Polish fact-checking organizations? Do they explicitly include an educational component in their activities?

RQ2: What types of educational activities are regularly held by the Polish factchecking organizations?

RQ3: What kind of MIL have the Polish fact-checking initiatives adopted?

By posing these three questions, the authors pursue a description of the existing factchecking organizations as pedagogical agents, embedded in the local conditions of promoting MIL.

\section{METHODOLOGY}

The authors implemented a two-step research design, which helps to answer the above-mentioned research questions. The first step was related to gathering secondary data, including a literature review and desk research. Also, the authors used documents and reports on the development of fact-checking in Poland, as well as official websites of Polish fact-checking groups and trade papers.

As a result of the desk research, the authors identified eight fact-checking initiatives in Poland. Generally, the authors could distinguish two types of fact-checking initiatives in Poland: (1) independent initiatives created by civil society actors and 
(2) initiatives created by the media. The first group is represented by two initiatives in our analysis: (1) Demagog and (2) Wojownicy Klawiatury. The second group is represented by six other projects: (1) OKO.press, (2) Konkret24, (3) Antyfake, (4) Demaskator24, (5) Trudat, and (6) Sprawdzam AFP.

The second step included qualitative research, as the authors conducted indepth, semi-structured interviews $(N=5)$ with key informants involved in Polish fact-checking initiatives, representing different types of fact-checking organizations. Two interviewees represented initiatives created by civil society actors and three additional initiatives created by media organizations. Considering the overall number of identified fact-checking organizations (eight) we assume that five interviews can be seen as relevant sample, even if not having statistical value.

The structure of the in-depth interviews consisted of six thematic groups of questions: (1) personal experience, (2) educational background, (3) organizations and its aims, (4) educational activities of a given organization, (5) profiling the participants of educational activities (if relevant), and (6) state-of-the-art fact-checking in Poland. The interviews were undertaken in the interviewees' native language (Polish), took place via a platform of the participant's choice (i.e., Skype or telephone), and were 35-60 minutes long, 46 minutes on average. All interviews were recorded and then transcribed verbatim in Polish. Afterwards, the authors produced an English-language report of approximately 2,000 words for each interview.

Collecting the interviewees' experience and knowledge about Polish fact-checking organizations, as well as the educational aspects of fact-checking, helped to determine the role of Polish fact-checkers as MIL agents. Primary data gathered during interviews with representatives of Polish fact-checking organizations (apart from data gathered during desk research) helped to present the organizations in a systematic way (Table 1), allowing a comparison of the following: objectives, declared attitudes towards educational activities, organizational structures, among others.

\section{THE POLISH FACT-CHECKING ORGANIZATIONS}

The body of literature dedicated to fact-checking beyond Western Europe or North America is not extensive. Still, there are some studies dedicated to different European initiatives, such as Finnish (Jaakkola, 2018) or Czech (Giereło-Klimaszewska, 2019). Prior studies have not presented more details about the Polish fact-checking scene, so the authors of this study were forced to rely mostly on primary data and some fragmented secondary data.

According to Duke Reporters' Lab (2020), which is an American center for journalism research in the Sanford School of Public Policy at Duke University, focusing on fact-checking, there were 225 active fact-checking projects in the World in 2019, including three in Poland. However, those numbers may be underestimated, as the case of Poland shows. The Polish initiatives mentioned by Duke Reporters' Lab include: OKO.press, Demagog, and Sprawdzam AFP. However, several other Polish 
platforms have launched recently, which do not yet feature in the Duke Reporters' Lab database. In total, the authors identified eight such initiatives in Poland. Considering that the development of fact-checking is globally diverse, with huge differences between the West and other parts of the world. Poland, with eight identified fact-checking organizations in total, seem to be part of the more developed factchecking sphere, at least in quantitative terms.

The number of fact-checking organizations working for profits has recently increased; at the same time, however, the number of non-profit and academic initiatives has gone down worldwide (Flamini et al., 2019). Some similarities can be observed in Poland, where there are no academic initiatives and the number of non-profit groups is small. However, when it comes to initiatives related to media, their number increased in 2018 and 2019. An example of this trend may be the emergence of Sprawdzam AFP and Antyfake in 2019 or Trudat and Konkret24 in 2018. Thus, initiatives created by the media and journalists constitute the majority of all fact-checking organizations in Poland.

The Polish fact-checking scene is still relatively young. A significant part (six out of eight) of the currently active (with different levels of activity) fact-checking platforms were launched between 2018 and 2019, in which many of them (i.e., Konkret24, Demaskator24, and Trudat) - thanks to the funding from Google's Digital News Initiative, a Pan-European program and part of the Google News Initiative - aimed to help develop journalism in the digital age (Google News Initiative, 2020).

Demagog, launched in 2014, was the first organization in Poland to become active in the field of fact-checking. The association (registered NGO) started verifying statements of politicians. Today, the main goal of Demagog is "to improve the quality of public debate by providing citizens with unbiased and reliable information" and also the "dissemination of the idea of fact-checking in Poland" (Demagog, 2019). On its official website, Demagog presents its main aims, mission, status, financial statements, analysis and reports, methodology, team members, and their main educational project (i.e., the Fact-Checking Academy).

Another initiative, created by civil society actors, is Wojownicy Klawiatury ("Keyboard Warriors"). It is an online community gathered around a Facebook account of the same name, including groups of more than 2500 members (as of February 2020), fighting against false information about the European Union on the web but also against fake news related to other topics. This group described itself as an open and transparent community based on the principles of volunteering. Wojownicy Klawiatury is organizationally associated with the European Front (i.e., an initiative created jointly by pro-European NGOs) and the Stefan Batory Foundation (i.e., a foundation supporting the development of democracy and civil society), but it is not a formal association or foundation. The group works primarily online, although it organizes educational meetings and workshops. 
The other six initiatives can be classified as created by the media. The oldest one among them is OKO.press, which is "a portal that checks facts and conducts journalistic investigations, a social medium and an archive of public life," as they describe themselves (OKO.press, 2019). The authors emphasize that the status of OKO.press is not so evident because it is a foundation and, at the same time, a registered non-profit media outlet. There is a permanent editorial board and they engage experienced journalists. Fact-checking is just one of the activities of this initiative, created by journalists. There is a section on the website, entitled "Prawda czy fałsz" ("True or false"), which presents an analysis of statements made by Polish politicians and public servants.

The next initiative is Konkret24, which is part of a media organization, TVN Group. TVN defines the main goal of the project is to "create an innovative, modern solution that allows to fight the phenomenon of disinformation not only through high-quality journalism, but also through cooperation with recipients" (TVN Media, 2018). The platform provides verification of statements, mainly but not only, from the political sphere.

Demaskator24 is also an initiative connected with a media organization, Polska Press Group. The aim is to fight against fake news that is common in the public space, as well as disinformation and propaganda (Demaskator24, 2018). The platform verifies information from different sources about politics, society, and economy but mainly from politicians.

The next initiative connected within the media industry is Sprawdzam AFP. Agence France Presse checks, as a third-party fact-checker, the accuracy of shared content on Facebook in Poland from the beginning of May 2019 (Sprawdzam AFP, 2019). On the website, Internet users can find verification of popular information, not only from the political sphere but also from society, scandals, environment, popular culture, and so on.

Trudat is also an initiative connected with the media, in this case naTemat Group. The fact-checking service was launched with the help of a grant from the Google Digital News Initiative. The editor-in-chief, Michał Mańkowski, claimed that Trudat is a place where information circulating on the Internet and media is verified, such as political issues but also myths about the daily lives of readers (Press, 2018).

The last fact-checking initiative in our analysis, Antyfake, is also the most controversial one. The owners of the platform were not so long ago accused of producing clickbait stories and fake news. Also, experts are critical or at least skeptical towards them, underlining that the website does not look like a classic fact-checking service and wondering if the actions are calculated just for short-term effects, as a response to criticism towards the media company that owns Antyfake (Dembowski, 2019). The platform verifies mainly information about politics. Aggregated information about Polish fact-checking organizations is presented in Table 1. 


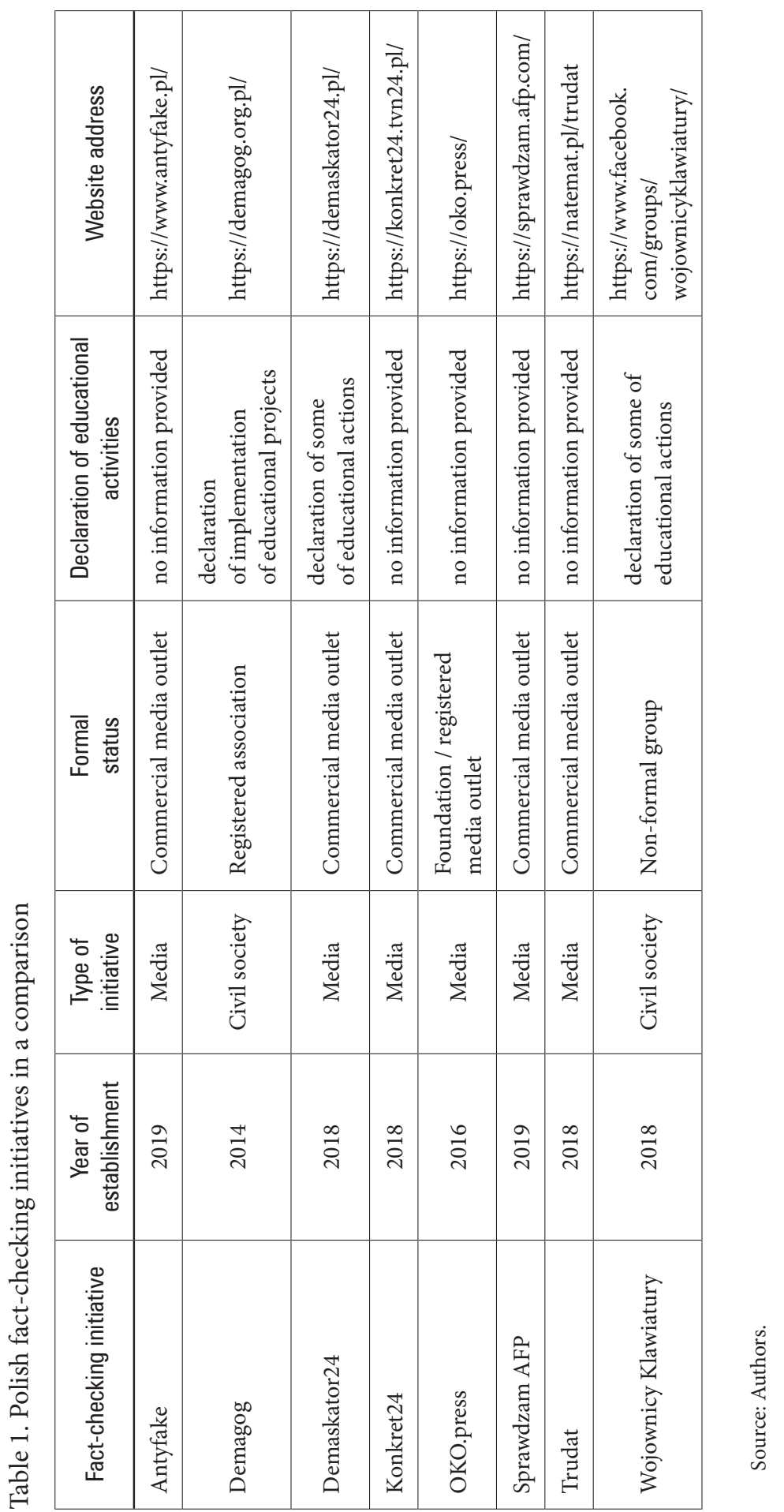


The Polish fact-checking initiatives represent different levels of development and maturity. Considering the history and scope of their activities, the present authors assessed that Demagog and Konkret24 are the most active ones. Considering the transparency of the fact-checking procedures, the authors observed that Demagog and OKO.press have clearly set out their verification procedures.

When it comes to the international context, the initiatives did not show involvement in transnational activities, with the exception of Demagog, which is one of many verified signatories of the International Fact-Checking Network's code of principles. The International Fact-Checking Network was launched in 2015 as a part of the Poynter Institute (2020), which is dedicated to connecting fact-checkers worldwide. Its aim is to make fact-checking a non-partisan and transparent instrument (International Fact-Checking Network, 2019). So far, none of the Polish initiatives have engaged in closer cooperation under European fact-checking projects. There is also no formal cooperation between groups operating in the country. They are usually aware of each other, but forms of cooperation have not been developed so far.

Considering RQ1, only one fact-checking organization explicitly declares the implementation of educational projects (Demagog) and two more (Demaskator24 and Wojownicy Klawiatury) declare that they engage in all types of educational activities. Therefore, it is noticeable that the declaration of educational function is a part of the mission but not a dominant approach of Polish fact-checking initiatives. However, the present authors also observe that fact-checking organizations created by civil society actors are visibly more active in this respect (see also section "The educational activities of the fact-checking initiatives").

\section{THE EDUCATIONAL ACTIVITIES OF THE FACT-CHECKING INITIATIVES}

The in-depth interviews focused on the involvement of Polish fact-checking organizations, with regard to their implicit or explicit educational activities. The interviews helped to identify at least some trends and tendencies in this respect. Despite the limited number of interviews, the interviews of the selected key informants covered most of the fact-checking organizations in Poland. Specifically, the interviewees represented five out of eight organizations, including the most active ones and both identified types of organizations (i.e., created by media and created by civil society groups).

\section{Direct and indirect approaches to education}

Basically, the interviews showed two approaches to educational activities: indirect and direct. Although the initiatives created by the media rather not focus on typical educational activities, their representatives frequently underline that fact-checking is an educational activity per se. Thus, the authors consider that approach as an 
indirect educational activity. According to one respondent, for example, "We don't implement education activity as such, but we hope that our actions teach society, our users to distinguish false information from truth" (respondent 2, media). Likewise, in the words of another respondent: "We operate only as a medium, publishing texts, publishing video materials, podcasts. Sometimes we organize some debate or conference, but we do not conduct fact-checking educational activities" (respondent 4, media).

The situation is different for initiatives created by civil society actors. Representatives of this group more frequently engage in different types of educational activities. Therefore, the authors consider that approach as a direct educational activity. For instance:

Since 2016 our organization started educational activities and from 2017, after presidential elections is US and Brexit referendum, we decided to develop complex educational activities. The other reason for that was lack of well-designed media literacy programs in Polish schools. (respondent 1 , civil society)

The goal is to educate citizens and Internet users to make them more aware. Making aware and showing examples of disinformation to accurately show what it looks like in practice and not just in theory. We have a research team that analyzes the news in Internet, finds fake news, factorize and shows where exactly lies manipulation. (respondent 3 , civil society)

Activists are more likely to play the role of media educators because journalists rather not define themselves as educators and perceive their role differently, even if they are involved in fact-checking and aim to increase awareness of media literacy and critical thinking. Civil society initiatives are directly involved in educating citizens and declare their vital importance in their activities. However, almost all respondents emphasized that the result of their activities should increase citizens' awareness and, as a consequence, lower their vulnerability to false news.

\section{Scope of activity of Polish fact-checking organizations}

All the fact-checkers interviewed acknowledge the scale of their activities and the scale of the problems related to false information. One of the respondents said that sometimes their work looks like "tilting at windmills" because only a small part of what appears in the media, including social media, is checked. Another interlocutor said that what they do is "is just a drop in the ocean of needs." Moreover, as one respondent stated, "Efficiency and relevance of many fact-checking initiatives is limited. Some of them publish posts rarely. Others do not cover politics" (respondent 5 , media).

There are also other limitations, mainly connected with human resources and financial resources. Respondents said that their teams are not very big and, at the same time, have a lot of tasks, which makes it problematic for them to operate on a larger scale and within the educational dimension. As one respondent contends: "We have a very small team for what we do" (respondent 4, media). As a result, 
according to another respondent: "Most of us engages in our fact-checking and educational activities in their free time. We usually have full-time jobs in other places" (respondent 1, civil society). Similarly:

The potential is very large. The only limiters are human and financial resources. At this point, various organizations, like Keyboard Warriors, do as much as they can and if these resources including personal ones - were larger, one could do much more and teach in schools and try to make young people aware of disinformation and fake news. (respondent 3 , civil society)

The problem of financial resources was also raised by the interviewees. Financial support could have a positive impact on the development of educational activities undertaken by fact-checking initiatives, especially non-governmental initiatives that are active in the educational field. Most of interviewees see funding and lack of calculable commercial potential as general sources of problems in Polish factchecking. In other words, "Money [is] the issue, no doubt about [it]. Fact-checking doesn't bring money. Operating such platform generated certain costs and it's not easy to cover all the necessary expenses" (respondent 5, media).

Limited visibility of fact-checkers in the media is another apparent weakness. Mainstream media rarely raises topics covered by fact-checking initiatives, usually just on the occasion of a disinformation report or monitoring of electoral irregularities. Thus, as one respondent contests:

There is visible lack of interest from big newsrooms. They don't cover or don't quote fact-checkers work. Our [fact-checkers] social media performance is also not satisfactory; we are still not able to attract the youngest audience. None of us could do it by now. (respondent 5 , media)

\section{Common challenges, different tools, and lack of system approach}

The interviews indicated that there are problems with polarization and information bubbles. All representatives of the studied fact-checking initiatives emphasized the role of promoting critical thinking in public life, but they prefer different tools to develop it. Again, this study has shown two approaches to shaping and disseminating critical thinking. The first emphasizes workshops, lectures, presentations, and other educational activities that can help educate citizens and make people aware of the scale of this disinformation and role of critical thinking. This approach is visible in activities undertaken by initiatives created by civil society actors. "The main two goals," according to one respondent, "are civic education and make people aware of the scale of this phenomenon [disinformation]" (respondent 3, civil society).

To create a spin-off effect, one of the fact-checking groups (from outside media sector) prepares materials (usually presentations) with different degrees of difficulty, depending on the knowledge of the volunteers. There are some materials with general information about disinformation, with a goal to get interested in this topic, but there are also more advanced presentations showing research tools. As one respondent contends: "The idea is that they can go to others, go out of the group and organize, for example, meetings in schools or on any other occasion, pass on knowledge on this topic" (respondent 3, civil society). 
The second one assumes that it is important to reach as many people as possible with fact-checking materials and, thus, make them aware of the problem of fake news and the importance of verification. In consequence, journalistic tools play an important role because they help draw the attention of the public. This approach is connected with initiatives created by the media or journalists. For instance:

Everyone who appeared in the OKO.press had a similar feeling that there was a need to create a place that would be quite popular and known. There is for instance Demagog, which is very reliable, but works on a much smaller scale than OKO.press do, articles appear much less often there and have a much more niche character than we have. From the beginning, we also wanted a high reach for what we do. (respondent 4 , media)

Respondents also noticed the general lack of a system approach to media education, especially towards formal education addressed to young citizens. It was pointed out by one of our interviewees that fact-checking classes should take place in every school. One of respondents said that it should be a big educational task not to lose trust in politics but also think critically and promote this way of thinking at all levels of education. Likewise, in the words of another respondent:

It is sad that there is no system approach to educate young citizens. In our opinion, such factchecking classes should take place in every school and should embrace every young person, because this is an element of using the web and each of the young people will come into contact with fake news. The question is whether they will know how they can verify a given information or whether they will be vulnerable. (respondent 3 , civil society)

One of fact-checking organizations is even actively engaged in some lobbying activities in this area. According to one respondent: "Apart from our main educational activities we also engage ourselves in lobbying activities, related to strengthening of media literacy presence in Polish schools" (respondent 1, civil society). This suggests that at least part of fact-checking organizations, mainly those representing the civic sector, would be interested in joining forces with structures of formal education, especially on the level of primary and secondary education.

\section{CONCLUSIONS AND DISCUSSION}

Considering the main research question, the authors observed that the Polish factchecking initiatives engage themselves occasionally in educational activities related to MIL. However, only some of them, mostly those related to civil society groups, treat their educational activities as a priority (RQ0).

Only one out of eight studied initiatives (Demagog, an NGO) explicitly include an educational component in its activities and consistently implements educational programs aimed at different target groups (RQ1). Concerning the types of educational activities implemented by Polish fact-checking organizations (RQ2) the authors distinguished two main levels of engagement: direct and indirect.

Direct educational activities mean explicit educational programs and projects, like courses for school children or students, workshops, lectures, meeting with 
experts, among others. The initiatives created by civil society actors visibly present greater determination in implementing such educational actions, despite the fact that they face various limitations, and it seems that their role in promoting media education may increase. However, it is strongly dependent on their financial and organizational resources.

Initiatives that form part of media organizations are not involved in such direct educational actions. Nevertheless, their representatives frequently declare that they treat fact-checking as an educational activity per se. Journalists, who usually represent the first type of initiatives, prefer an indirect approach, in which factchecking increases the awareness of disinformation, fake news, and role of information verification.

Fact-checking organizations involved in educational activities treat themselves as agents of non-formal education (RQ3). However, they willingly cooperate with institutions related to formal education systems.

System and financial support could probably increase the scale of this activity to provide valuable support for institutions of formal education, which still (at least in Poland, where MIL is typically understood in a narrow way and connected mainly with IT skills) appears not to equip young citizens with knowledge about the problems faced by contemporary media users. Experts point out that in the Polish education system, there is no clear definition of media education and this area needs constructive changes (Brosch, 2017).

On the other hand, precise indication of effects of educational activities implemented by Polish fact-checking organizations is difficult. All examined organizations declare that their activities should increase the awareness of disinformation and fake news among citizens. Representatives of civil society fact-checking initiatives also added that they see effects in groups of people who learned a lot during workshops, lectures, and other trainings and meetings. However, an exact description of real effects will require additional research.

\section{REFERENCES}

Agadjanian, A., Bakhru, N., Chi, V., Greenberg, D., Hollander, B., Hurt, A., Kind, J., Lu, R., Ma, A., Nyhan, B., Pham, D., Qian, M., Tan, M., Wang, C., Wasdahl, A., \& Woodruff, A. (2019). Counting the Pinocchios: The effect of summary fact-checking data on perceived accuracy and favorability of politicians. Research \& Politics, 6(3), 1-10. https://doi.org/10.1177/2053168019870351.

Bennet, L., \& Livingston, S. (2018). The disinformation order: Disruptive communication and the decline of democratic institutions. European Journal of Communication, 33(2), 122-139. https://doi. org/10.1177/0267323118760317.

Brosch, A. (2017). Media education in Poland - needs versus reality. Journal of Technology and Information Education, 9(1), 307-317. http://doi.org/10.5507/jtie.2017.030.

Bradshaw, S., \& Howard, P. N. (2018). The global organization of social media disinformation campaigns. Journal of International Affairs, 71(1.5), 23-32.

Carlsson, U. (Ed.) (2019). Understanding media and information literacy (MIL) in the digital Age: A question of democracy. Department of Journalism, Media and Communication (JMG). 
Demagog (2019). Stowarzyszenie [Association]. https://demagog.org.pl/stowarzyszenie-demagog-pierwsza-w-polsce-organizacja-factcheckingowa/.

Demaskator24 (2018). Demaskator24.pl - wszystko o naszej inicjatywie [Demaskator24.pl - everything about our initiative]. https://demaskator24.pl/o-nas.

Dembowski, P. (2019). Byty właściciel serwisu z fake newsami uruchomił witrynę, która ma z nimi walczyć [Former owner of fake news website opens fact-checking website]. https://www.press.pl/ tresc/57070,byly-wlasciciel-serwisu-z-fake-newsami-uruchomil-witryne_-ktora-ma-z-nimi-walczyc.

Dizikes, P. (2018). Study: On Twitter, false news travels faster than true stories. http://news.mit.edu/2018/ study-twitter-false-news-travels-faster-true-stories-0308.Duke Reporters' Lab (2019). Global factchecking sites. https://reporterslab.org/fact-checking/.

Farkas, J., \& Schou, J. (2019). Post-truth, fake news and democracy: Mapping the politics of falsehood. Routledge.

Flamini, D., Tardáguila, C., \& Örsek, B. (2019). For-profit fact-checking is on the rise, and more teams have full-time employees. Poynter. https://www.poynter.org/fact-checking/2019/for-profit-factchecking-is-on-the-rise-and-more-teams-have-full-time-employees/.

Flore, M., Balahur, A., Podavini, A., \& Verile, M. (2019). Understanding citizens' vulnerabilities to disinformation and data-driven propaganda. Publications Office of the European Union.

Frau-Meigs, D., Velez, I., \& Michel, F.J. (Eds.) (2017). Public policies in media and information literacy in Europe: Cross-country comparisons. Routledge.

Freedom House. (2018). Freedom in the world 2018: Democracy in crisis. https://freedomhouse.org/report/freedom-world/freedom-world-2018.

Giereło-Klimaszewska, K. (2019). Political fact-checking in the Czech Republic on the example of demagog.cz and manipulatori.cz portals. Mediatization Studies, 3(1), 115-135. http://dx.doi. org/10.17951/ms.2019.3.115-135.

Głowacki, M., \& Kuś, M. (2019). Media accountability meets media polarisation: A case study from Poland. In T. Eberwein, S. Fengler, \& M. Karmasin (Eds.), Media accountability in the era of post-truth politics (pp. 100-116). Routledge.

Google News Initiative (2020). Digital news innovation fund. https://newsinitiative.withgoogle.com/ dnifund/.

Graves, L. (2016). Deciding what's true: The rise of political fact-checking in American journalism. Columbia University Press.

Graves, L., \& Cherubini, F. (2016). The rise of fact-checking sites in Europe. Reuters Institute. https://reutersinstitute.politics.ox.ac.uk/sites/default/files/research/files/The\%2520Rise\%2520of\%2520FactChecking\%2520Sites\%2520in\%2520Europe.pdf.

Graves, L., \& Amazeen, M. (2019). Fact-checking as idea and practice in journalism.

Oxford research encyclopedia of communication. http://doi.org/10.1093/acrefore/9780190228613.013.808

Grizzle, A. (2016). A Context: MIL as a tool to counter hate, radicalization and violent extremism Introduction. In J. Singh, P. Kerr, \& E. Hamburge (Eds.), Media and information literacy: reinforcing human rights, countering radicalization and extremism (pp. 11-22). UNESCO.

Helsińska Fundacja Praw Człowieka. (2020). Fake newsy i dezinformacja w kampaniach wyborczych w Polsce $w 2019$ roku - raport z obserwacji [Fake news and disinformation in the election campaigns in Poland in 2019 - a final report]. http://www.hfhr.pl/wp-content/uploads/2020/02/Fake-newsyi-dezinformacja_final.pdf?fbclid=IwAR2wzjQmrXR3aH5j3LyoB78yvJe3gaP6VFVB5sZ84DpDDy Q06a2rHzWwJvs.

International Fact-Checking Network (2019). Verified signatories of the IFCN code of principles. https:// ifcncodeofprinciples.poynter.org/signatories.

Jaakkola, M. (2018). Against fake information and for voter literacy: Fact-checking initiatives form a major pedagogical mission. Nordicom-Information, 40(1), 81-85. 
Lessenski, M. (2019). Just think about it: Findings of the Media Literacy Index 2019. https://osis.bg/wpcontent/uploads/2019/11/MediaLiteracyIndex2019_-ENG.pdf.

Lim, C. (2018). Checking how fact-checkers check. Research \& Politics 5(3), 1-7. https://doi.org/10 $.1177 / 2053168018786848$.

European Audiovisual Observatory (2016). Mapping of media literacy practices and actions in EU-28. Retrieved January 15, 2020, from https://rm.coe.int/0900001680783500.

McQuail, D. (2020). McQuail's mass communication theory (6th ed.). Sage Publications.

Nielsen, R. K., \& Graves, L. (2017). "News you don't believe": Audienceperspectives on fake news. Reuters Institute. https://reutersinstitute.politics.ox.ac.uk/sites/default/files/2017-10/Nielsen\%26Graves_facts heet_1710v3_FINAL_download.pdf.

OKO.press (2019). Po co OKO? [Why OKO?] https://oko.press/o-nas/.

Press (2018). Grupa NaTemat uruchomiła serwis fact-checkingowy Trudat.pl [NaTemat Group has started fact-checking website Trudat.pl]. https://www.press.pl/tresc/52431,grupa-natemat-uruchomilaserwis-fact-checkingowy-trudat_pl.

Sprawdzam AFP (2019). Fact-checking w AFP [Fact-checking in AFP]. https://sprawdzam.afp.com/factchecking-w-afp.

The Poynter Institute (2020). The international fact-checking network. https://www.poynter.org/ifcn/.

TVN Media (2018). Nowy portal dziennikarski - Konkret24 [New journalistic portal - Konkret24]. Retrieved January 10, 2020, from https://www.tvnmedia.pl/aktualnosci/online/konkret24.

Vosoughi, S., Roy, D., \& Aral, S. (2018). The spread of true and false news online. Science, 359(6380), 1146-1151. https://doi.org/10.1126/science.aap9559.

Wardle, C., \& Derakhshan, H. (2017). Information disorder: Toward an interdisciplinary framework for research and policy making. https://rm.coe.int/information-disorder-toward-an-interdisciplinaryframework-for-researc/168076277c.

Wineburg, S., McGrew, S., Breakstone, J., \& Ortega, T. (2016). Evaluating information: The cornerstone of civic online reasoning. Standford Digital Repository. http://purl.stanford.edu/fv751yt5934. 